


\title{
Age estimation by pulp/tooth area and width ratios in panoramic images of upper and lower canines among the Iranian population
}

Estimativa da idade por área de polpa/dente e relações de largura em imagens panorâmicas de caninos superiores e inferiores entre a população iraniana

Roghieh BARDAL ${ }^{1}$, Mitra SOLTANI ${ }^{2}$

1 - Department of Oral and Maxillofacial Radiology, Dental Caries Prevention Research Center, Qazvin University of Medical Sciences, Qazvin, Iran.

2 - Student Research Committee, Qazvin University of Medical Sciences, Qazvin, Iran.

\section{ABSTRACT}

Objective: One of the techniques of estimating age in forensic medicine, which is associated with the least trauma in both living individuals and corpses, is to use teeth. Accordingly, the present study aims to determine the relationship between chronological age and pulp-to-tooth area ratio and pulp-to-root width ratio in maxillary and mandibular canines on panoramic radiographs among the Iranian population. Material and Methods: A total of 162 panoramic radiographs were evaluated in the present study. Selected patients were of verified age with the age range of 15-45 years. The pulp-totooth area ratio (PTR) and the pulp-to-root width ratio were calculated with AutoCAD 2016 software program in maxillary and mandibular canines at two points of the root. The two points include cementoenamel Junction (CEJ) and pulp/root width at the quarter of a distance between CEJ and end point of root-canal, which was named WA, WB respectively. The patients' age was also estimated with the use of linear regression equation. Then each patient's chronological age and the age estimated using this technique was compared. Results: The relationship between PTR in both canines and WB variable in maxilla with chronological age was inverse and significant $(\mathrm{P}<0.05)$; However, there was no strong correlation coefficient $(r \leq-0.37)$. Gender had no effect on the results of the study. The mean difference between predicted age and actual age with combined PTR and WB formula was lower than 1 year. When the mean of PTR or WB variables was considered as a predictor, significant results were obtained ( $P$ $<0.05$ ), showing a decrease in Standard error of estimation (SEE). The results were not significant when variables of upper PTR and lower PTR and the interaction between them were included in the

\section{RESUIMO}

Objetivo: Uma das técnicas de estimativa da idade na medicina legal, que está associada ao menor trauma em indivíduos vivos e cadáveres, é usar os dentes. Nesse sentido, o presente estudo tem como objetivo determinar a relação entre a idade cronológica e a relação área polpa-dente e relação largura-polpa-raiz em caninos superiores e inferiores em radiografias panorâmicas na população iraniana. Material e Métodos: Um total de 162 radiografias panorâmicas são avaliadas no presente estudo. Os pacientes selecionados são da idade verificada com a faixa etária de 15-45 anos. A relação de área polpa-dente (PTR) e a relação largura-polpa-raiz são calculadas com o programa de software AutoCAD 2016 em caninos superiores e inferiores em dois pontos da raiz. Os dois pontos incluem a junção cementoesmalte (CEJ) e a largura da polpa / raiz no quarto de distância entre a CEJ e o ponto final do canal radicular, que é denominado WA, WB. A idade dos pacientes também é estimada com o uso da equação de regressão linear. Em seguida, a idade cronológica de cada paciente e a idade estimada usando esta técnica são comparadas. Resultados: A relação entre a PTR em ambos os caninos e a variável WB na maxila com a idade cronológica é inversa e significativa ( $\mathrm{P}$ $<0,05)$; No entanto, não existe um coeficiente de correlação forte ( $r \leq-$ o.37). O gênero não tem efeito nos resultados do estudo. A diferença média entre a idade prevista e a idade real com a combinação de PTR e fórmula WB é inferior a 1 ano. Quando a média das variáveis PTR ou WB é considerada como preditora, resultados significativos são obtidos (P $<0,05)$, mostrando uma diminuição no SEE. Os resultados não são significativos quando as variáveis de PTR superior e PTR inferior e a interação entre elas são incluídas no modelo de regressão linear 
linear regression model $(\mathrm{p}>0.05)$. Same results were obtained with the variable of WB. Conclusion: Combining the variables of PTR and WB gives better results than using variables alone. Estimation of age with the mean of each variable shows less error than their combination.

\section{KEYWORDS}

Age determination; Canine; Panoramic radiography. (p> 0,05). Os mesmos resultados são obtidos com a variável de WB. Conclusão: Combinar as variáveis de PTR e WB dá melhores resultados do que usar variáveis sozinhas. A estimativa da idade com a média de cada variável apresenta menos erros do que sua combinação.

\section{PALAVRAS-CHAVE}

Determinação da idade; Canino; Radiografia panorâmica.

\section{INTRODUCTION}

$\mathrm{E}_{\text {hem }}^{\mathrm{s}}$ stimation of an individual's age during his/ her life is an important issue in forensic medicine. In cases where it is necessary to determine an individual's age, such as in crimes, accidents, illegal immigration with unknown age and identity or when an individual's age is not known for any reason, such as memory loss, and etc., determination of age is a very sensitive issue $[1,2]$.

Different medical techniques have been used to estimate age to date. One of these techniques relies on the individual's dentition. Teeth have the hardest structure in the human body and are the most resistant parts to the use of medications, endocrine diseases and chemical and thermal changes, making them an ideal tissue for the estimation of age in both living individuals and corpses [3].

The first effective method for estimating age in corpses using teeth was introduced by Gustafson in 1950, which consisted of determination of the amount of secondary dentin [4]. some of the different techniques used for the estimation of age using teeth are the use of tooth structure, observation of tooth collagen, Lamendin technique, and etc., which have some limitations [5]. Some of these limitations are the complexity and the potential to destroy tooth structure and the need for extraction of teeth, making them unpractical in living individuals [6].
In contrast, radiographic techniques of age determination by teeth are a simple, nondestructive and reliable method [7] that do not require extraction of teeth, being practical in living individuals [8] . In two-dimensional radiographic techniques, such as periapical and panoramic techniques, it is possible to calculate the pulp-to-tooth area ratio and pulp-to-root width ratio.

Kvaal et al. (1995) used periapical radiographs of 6 teeth, consisting of 3 maxillary and 3 mandibular teeth. They indirectly determined the amount of secondary dentin deposition with the use of pulp-to-tooth area ratio on periapical radiographs for the first time and reported a significant relationship between the amount of secondary dentin deposited and an individual's age [9] . However, Paewinsky et al. (2005) modified the technique used by Kvaal. They used panoramic radiographs instead of periapical radiographs for the estimation of age and showed a significant relationship between the pulp-to-root width ratio at different areas of the root and the chronological age [10] . Some researchers have reported that given the limitations of evaluation of maxillary teeth on panoramic radiographs, it is advisable to evaluate mandibular teeth for the estimation of age. These limitations include superimposition of adjacent structures and maxillary teeth and a lack of image resolution and sharpness [11] . However, some researchers have used maxillary canines for estimating age regardless of such limitations [12-17] . 
In 2007, Cameriere et al. recommended future researchers to investigate "the effect of race and culture in model parameters" for age estimation by pulp/tooth Ratio [18]. Indeed, others have also advocated the verification of age estimation methods on independent samples and some have concluded that best results are derived when population specific formulas are used [9, 19]. Babshet et al. and Saxena found that Cameriere's formula, based on the Italian population, is not as applicable to the Indian population $[9,11]$.

Age estimation with panoramic radiography among Iranian population has been studied in some studies; however, comparison of upper and lower canine results with pulpto-tooth area ratio in Dehghani et al. (2018) and pulp-to-tooth area ratio and width ratios together in the Iranian population in this study can answer this question that which tooth/ teeth and ratio/ratios are more accurate for age estimation in this population [15, 20-22] . For this reason, this study aims to estimate chronological age with pulp-to-tooth area ratio and width ratios of upper and lower canines on panoramic radiographs among Iranian population.

\section{MATERIALS AND METHODS}

This study approved by ethical committee of Qazvin University of Medical Sciences with ethical number of IR.QUMS.REC.1395.162. Sample size was calculated according to the following formula:

$$
n=\frac{z^{2} s^{2}}{d^{2}}
$$

$$
s=0.039 ; z=1.96 ; d=0.006 ; n=162
$$

Adult patients referring to the Oral and Maxillofacial Radiology Department, Qazvin Faculty of Dentistry, for routine dental treatment from 2016 to 2017 entered the study based on inclusion criteria. These criteria in the clinical examination were age over 15 years, lack of any developmental, hormonal and nutritional deficiencies, lack of any specific dental disease or anomaly such as obvious caries, dental wear, size or shape malformations, deep or open bite occlusion, history of dental trauma and so on. People over 45 years were excluded from the study because most of the clinically examined subjects showed different grades of attrition.

The radiographs were evaluated for sharpness of the relevant teeth, contrast and brightness. Radiographs with severe curvature of the root, widespread enamel overlapping, any shape of root or crown fillings, and pathologic conditions, such as caries, periapical or periodontal diseases, and crown or root fractures were excluded from the study. Finally, a total of 162 panoramic radiographs of these patients (57 males and 105 females) were selected.

According to the study by Kvaal et al., right and left side results of the jaw didn't have any significant differences [9].Consequently; the analytic study was carried out on two teeth irrespective of the right or left side.

Cases with overlapping maxillary canines, only mandibular canine was included. The teeth evaluated consisted of 99 maxillary canines and 142 mandibular canines in 105 women and 57 men.

The panoramic radiographs were taken by Ray Scan digital panoramic devise, with KVP of $69-80, \mathrm{~mA}$ of $9-13$ and duration of 13.6-14 seconds. Panoramic images were processed using the AutoCAD software of 2016developed by Autodesk on a Sony laptop, model VPCEA24FM.Observer allowed to justify contrast and brightness of the images before measuring processes.

Twenty random points on the tooth periphery and ten points around the pulp outline of the upper and lower canines were identified [22]. Pulp area was then evaluated (Figure1: a-c). 
The pulp length and root length were measured. The width of the root and pulp was measured at 2 different levels, one at the cemento-enamel junction(CEJ) and the second at the quarter of a distance between CEJ and end point of root-canal (9) (Figure1: d-f). All measurements were done by a single observer, who was a general dentist. In order to evaluate the measurements' reliability, 20 radiographs were randomly selected to be compared with maxillofacial radiologist measurements.

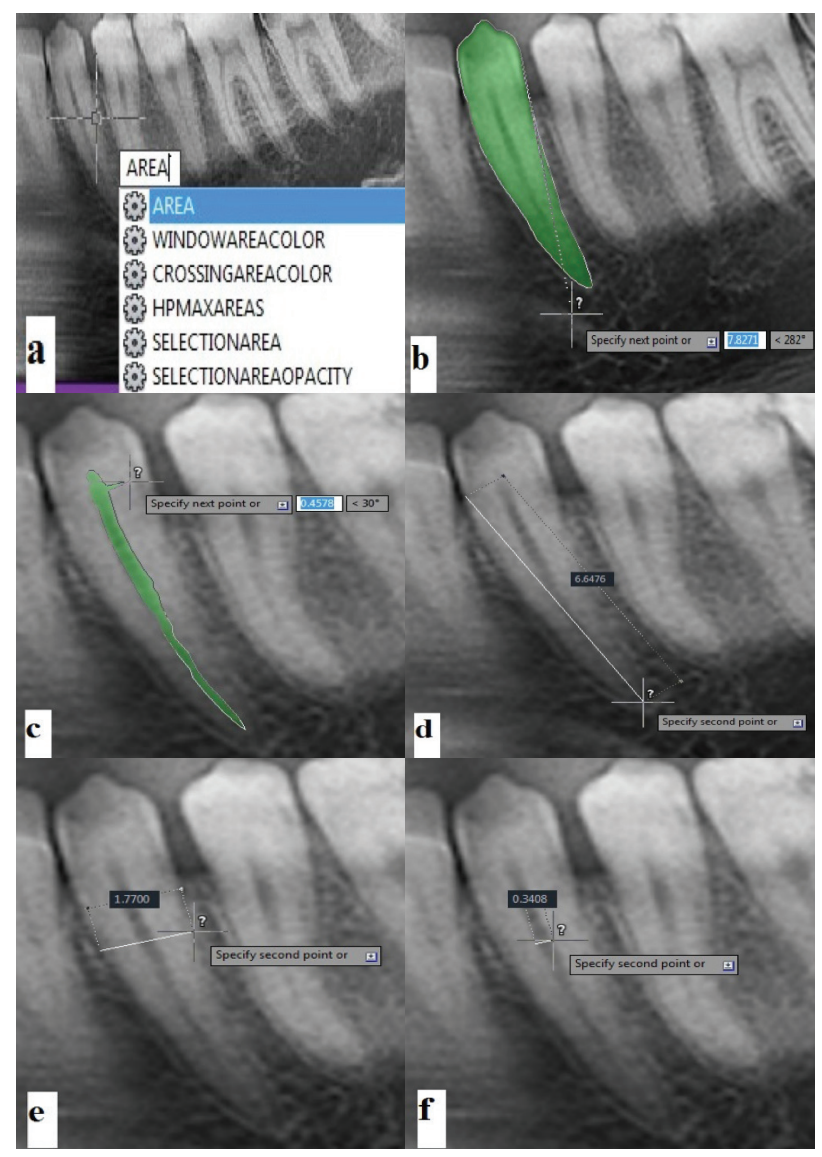

Figure 1 - a-c: Shows area measurement of the tooth and pulp, d-f: Shows root length, root width and, pulp width measurements at the fourth distance of this length respectively (point B).

\section{Statistical analyses}

The following tooth ratios were recorded: $\mathrm{PTR}=$ pulp /tooth area ratio, $\mathrm{WA}=$ pulp/ root width ratio at CEJ level, and $\mathrm{WB}=$ pulp/ root width ratio at the quarter of a distance between CEJ and end point of root-canal. Statistical analysis was performed by means of SPSS-21.0 program. Test distribution of sample was done with the Kolmogorov-Smirnov test and was confirmed ( $\mathrm{P}>0.05)$. T-test was also used to measure means' equality and Levene's test was used to investigate variances' equality of data. Group statistics between males and females was done with T-test according to morphological variables. Pearson correlation coefficients between chronological age and the predictive variables were also calculated. Linear regression is performed between each variable, combination of variables and actual age as a depended variable. In addition, $\mathrm{P}<0.05$ was considered significant. T-test was used to paired differences between actual age and predicted age.

\section{RESULTS}

Females and males comprised $64.8 \%$ and $35.2 \%$ of the subjects, respectively. The age range of the subjects was 15-45 years, with a mean age of $28 \pm 7.5$ years. Frequency distribution of samples is shown in Table I. T-test results showed that there was no significant difference between morphological variables of males and females $(P>0.05)$.

Table II presents the Pearson correlation between the chronological ages and pulp-totooth area ratio and pulp-to-root width ratio of maxillary and mandibular canines.

The results (Table II) showed that variables of PTR and WB in maxillary canine and PTR in mandibular canine are significantly correlated with chronological age $(\mathrm{P}<0.05)$. Table III presents age estimation formula based on PTR and WB variables, with the combination of two variables yielding the following formulas:

Calculated age with the maxillary canine $=42.75-13.1(\mathrm{PTR})-59.6(\mathrm{WB})$ 
Calculated age with the mandibular canine $=43.8-105(\mathrm{PTR})-4(\mathrm{WB})$

In graphs 1 and 2 , the estimated age is calculated with above formulas, showing that the variables are equally distributed. Also, the mean difference between predicted age and actual age was lower than 1 year and p-value $\geq 0.95$, so age estimation was done well. SEE was .25 and .26 years for maxillary and mandible canines, respectively (Table IV). In linear regression, PTR mean and WB mean variables were considered as predictors (constant) and age as a dependent variable and the results were significant $(\mathrm{P}<$ 0.05); SEE was 6.6 and 5.5 years for PTR mean and $\mathrm{WB}$ mean variables, respectively. The results were not significant when the variables of upper PTR and lower PTR and the interaction between them were included in the linear regression model $(\mathrm{P}>0.05)$. The mean difference between actual age and predicted age was lower than 1 year with PTR u (upper canine), PTRu (lower canine), WB u and the mean of these variables (Table V).

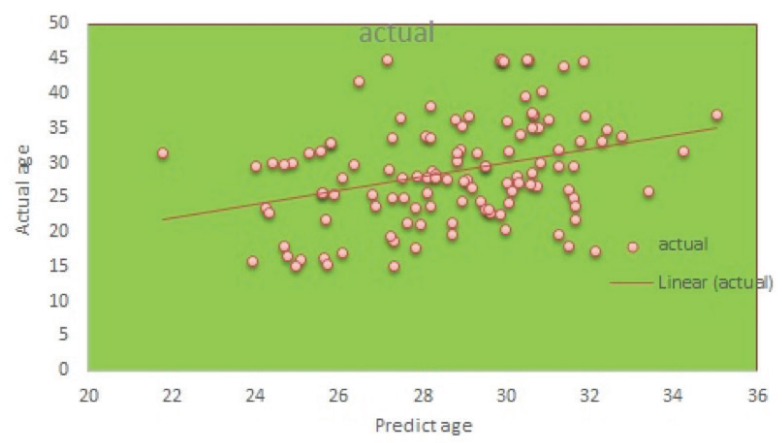

Graph 1 - Scatter plot of predicted age vs. chronological age with maxillary canines.



Graph 2 - Scatter plot of predicted age vs. chronological age with mandibular canines.
Table I - Age- and sex-wise distribution of patients included in the study

\begin{tabular}{|c|c|c|c|c|c|}
\hline \multicolumn{6}{|c|}{ Sex } \\
\hline \multirow{2}{*}{$\begin{array}{l}\text { Groups } \\
\text { (years) }\end{array}$} & \multicolumn{2}{|c|}{ Male } & \multicolumn{2}{|c|}{ Female } & \multirow{2}{*}{ Total } \\
\hline & Number & Percent & Number & Percent & \\
\hline$<25$ & 16 & 28.1 & 42 & 40 & 58 \\
\hline $25-35$ & 30 & 52.6 & 46 & 43.8 & 76 \\
\hline $35-45$ & 11 & 19.3 & 17 & 16.2 & 28 \\
\hline Total & 57 & 100 & 105 & 100 & 162 \\
\hline
\end{tabular}

Table II - Pearson Correlation between chronological age and variables PTR, WA and WB

\begin{tabular}{|cccccccc|}
\hline Tooth & \multicolumn{2}{c}{ PTR } & \multicolumn{2}{c}{ WA } & \multicolumn{2}{c|}{ WB } \\
\hline upper canine & $\mathbf{r}$ & -0.2 & $\mathbf{P}$ & $\mathbf{r}$ & $\mathbf{P}$ & $\mathbf{r}$ & $\mathbf{P}$ \\
\hline Lower canine & -0.03 & 0.07 & ${ }^{*} 0.00$ & -0.12 & 0.24 & -0.37 & ${ }^{*} 0.04$ \\
\hline
\end{tabular}

$r=$ the correlation between age and this ratio; $P=P$-value: ${ }^{*}=P<0.05$ was set as statistical significance

Table III - Calculation of age with tooth ratios of maxillary and mandibular canines

\begin{tabular}{|c|c|c|}
\hline Tooth & $\begin{array}{c}\text { Calculated age with } \\
\text { PTR }\end{array}$ & $\begin{array}{c}\text { Calculated age with } \\
\text { WB }\end{array}$ \\
\hline Upper canine & 31.3-29(PTR) & 42-67.4 (WB) \\
\hline lower canine & 43.6-110 (PTR) & \\
\hline $\begin{array}{l}\text { Mean Upper\& Lower } \\
\text { Canines }\end{array}$ & 42.24-101.82(PTR) & $45.58-80.75(\mathrm{WB})$ \\
\hline
\end{tabular}

Table IV - Regression analysis of combined variables

\begin{tabular}{|c|c|c|c|c|c|}
\hline \multirow[t]{2}{*}{ Model } & & \multicolumn{2}{|c|}{$\begin{array}{l}\text { Unstandardized } \\
\text { Coefficients }\end{array}$} & \multirow{2}{*}{$\begin{array}{c}\text { Standardized } \\
\text { Coefficients } \\
\text { Beta }\end{array}$} & \multirow[t]{2}{*}{$\mathbf{t}$} \\
\hline & & B & Std. Error & & \\
\hline \multicolumn{6}{|c|}{ Coefficients with formula combined PTR and WB } \\
\hline (Constant) & -0.023 & 6.971 & & -0.003 & 0.997 \\
\hline $\begin{array}{l}\text { Predicted age in } \\
\text { maxilla }\end{array}$ & 1.001 & 0.257 & 0.395 & 3.899 & 0.000 \\
\hline (Constant) & -0.023 & 7.610 & & -0.003 & 0.998 \\
\hline $\begin{array}{l}\text { Predicted age in } \\
\text { mandible }\end{array}$ & 1.001 & 0.264 & 0.332 & 3.792 & 0.000 \\
\hline \multicolumn{6}{|c|}{ Coefficients with mean variables of upper and lower canines } \\
\hline (Constant) & 42.248 & 6.670 & & 6.334 & 0.000 \\
\hline PTR & -101.829 & 48.868 & -0.317 & -2.084 & 0.044 \\
\hline (Constant) & 45.587 & 5.585 & & 8.162 & 0.000 \\
\hline WB & -80.759 & 26.187 & -0.434 & -3.084 & 0.004 \\
\hline
\end{tabular}

a. Dependent Variable: Actual age. 
Table V - Difference in means and 95\% Cl between actual age and predicted age

\begin{tabular}{|ccccccc} 
& PTRU & PTRL & PTRmean & WBU & WBmean \\
\hline Mean \pm SD & $-0.002 \pm 6.74$ & $0.01 \pm 7.08$ & $-04 \pm 5.99$ & $-0.002 \pm 6.58$ & $0.04 \pm 5.57$ \\
$\begin{array}{c}\text { Std. Error } \\
\text { of Mean }\end{array}$ & 0.73 & 0.65 & 0.93 & 0.70 & 0.85 \\
\hline $95 \% \mathrm{Cl}$ & $\begin{array}{c}\text { Lower } \\
\text { limit }\end{array}$ & -1.46 & -1.29 & -1.89 & -1.37 & -1.71 \\
& $\begin{array}{c}\text { Upper } \\
\text { limit }\end{array}$ & +1.46 & +1.29 & +1.88 & +1.37 & +1.72 \\
\hline
\end{tabular}

The indices $U$ and $L$ stand for upper and lower canines, respectively.

\section{DISCUSSION}

Continuous deposition of secondary dentin during life results in a decrease in pulp area and width. Deposition of tertiary dentin is promoted by factors such as erosion, abrasion, attrition, caries, changes in the osmotic pressure within the pulp, and so on. All these factors are in fact pathologic, but the deposition of secondary dentin with age occurs as a physiologic process in the absence of pathologic factors [23-25]. Based on previous studies, these physiologic changes have a significant relationship with aging and it is possible to estimate chronological age by determining the pulp-to-tooth area ratio and the pulp/root width. It is, however, simple, non-destructive method that can be used in the identification of living individuals or unknown dead persons [9]. Other uses of age estimation are in cases of immigrants (legal or otherwise) without concrete proof of age and birth records; age estimation is also useful to determine the status of majority (e.g. runaway brides). Therefore, age estimation covers children, adolescents, and adult age groups [26].

Periapical radiographs are more accurate than panoramic radiographs, with less distortion, but it is not always possible to take periapical radiographs of intact teeth [27].

Several studies have shown the efficacy of panoramic radiographs in the estimation of age [28]. However, the accuracy of these radiographs for the estimation of age depends on the accuracy of measurements and the quality of these radiographs. Factors, such as tooth distortion due to improper patient positioning, unequal magnification in the horizontal and vertical dimensions [29], superimposition of adjacent structures on teeth, especially in the maxilla ,poor resolution of images that makes it difficult to diagnose the reference points on the tooth, draw reference lines, and calculate tooth surface area [30], are some disadvantages of panoramic images. Some of its advantages are the possibility to evaluate all patients' teeth on one radiograph and the possibility to use panoramic radiographs, which have been taken for other reasons.

The study was limited to the canines because it is the long lasting tooth [14], the easiest to be analyzed due to largest pulp area among all the single rooted teeth $[15,18,27]$, and undergoes less erosion compared to other teeth [27] .

In the present study, gender had no effect on the results, which was similar to the findings of previous studies [14,22,31]. PTR in both canines and WB in upper canine exhibited a significant inverse relationship with aging $(\mathrm{P}<0.05)$. Correlation coefficients of these variables with aging were close, a slightly better correlation was seen with the maxillary WB variable.

The relationship between PTR of both upper and lower canines with age was assessed on periapical images in the studies of Cameriere et al. and Jeevan et al.

The study of Cameriere et al. [18] was performed on skeletons of Caucasian origin and the study of Jeevan et al. [32] was conducted on an Indian sample, assessing the relationship between PTR with age on periapical images in both upper and lower canines. Correlation coefficients obtained in these studies were 
close to each other, which was in line with this study. However, in the study of Dehghani et al. [22] that was conducted on panoramic radiographs of an Iranian sample, correlation coefficient of maxillary canine was about three times higher than that achieved for lower canine. In panoramic radiographs, inherent image distortion can affect the accuracy of the measurements, so difference in results could be attributed to patient positioning during taking radiographs. With slightly downward rotation of chin and occlusal plane, maxillary canine images are less distorted than mandibular canine.

Mean difference between actual age and predicted age was lower than 1 year and SEE was 6.58 to 7.08 years with PTR in both canine and WB in upper canine. Several studies accepted that a standard deviation of around \pm 10 years is normal.

SEE was lower than 1 year using the formula derived with combined PTR and WB of each jaw. In linear regression, predicted age with this formula was constant and actual age was the dependent variable, showing that this relationship is statistically significant ( $P$ $=0.00)$; SEE was decreased significantly in relation to each variable alone. In the study of Juneja et al. [12] that was done on adults of Karnataka origin, the mean difference between predicted age and actual age was lower than 1 year using the formula derived with combined PTR and WB of maxillary canine, which was consistent with the results of this study.

When the mean of PTR or WB variables was considered as a predictor (constant) in linear regression analysis and age as a dependent variable, the results were significant ( $\mathrm{P}<0.05)$; and SEE was slightly decreased (SEE of 6.6 years with PTR and SEE of 5.5 years with WB variables). It can be concluded that intrinsic distortion in panoramic image scan is compensated with the mean variables.
When the upper PTR and lower PTR and the interaction between them were included in linear regression, the results were not significant $(P>0.05)$. The same results were obtained with the WB variable. Cameriere et al.'s study on periapical radiographs of Caucasian origin skeletons [18] showed that when both upper and lower PTR of canines were included in the regression model, the coefficient of determination was slightly weaker in comparison to the coefficient of determination with these variables alone, which was in line with the results of the present study. Since the coefficient of determination of each of the variables $(R=0.92)$ was higher than that of the present study, their interaction was still significant.

These interesting results showed that which method used in above studies is better in age estimation on panoramic images among Iranian samples. However, there weren't sufficient samples of up to 45 years, because subjects with any grades of attrition were excluded. The number of samples was low, so there was no sub-group analysis. It is recommended to replicate this study with all adult ages, more samples in each group, and another panoramic devise with higher resolution.

\section{CONCLUSION}

It can be concluded that there is a significant correlation between age, both canine PTRs, and upper canine WB variables. Combining the variables of PTR and WB gave better results than using each variable alone. Estimation of age with the mean of each variable showed less error than their combination among Iranian samples and can compensate the panoramic images' distortions.

\section{Funding}

None. 


\section{Competing Interests}

The authors declare that they have no competing interest

\section{Acknowledgments}

The authors are grateful to Tina Bakhtiari for content contributions, Shiva Esmaeili for their critical review of the manuscript and the faculty of dentistry, Qazvin University of Medical Sciences for support during the development and writing of this manuscript.

\section{Regulatory Statement}

This study was conducted in accordance with all the provisions of the local human subject's oversight committee guidelines and policies of: ethical committee of Qazvin University of Medical Sciences. The approval code for this study is: IR.QUMS.REC.1395.162.

\section{REFERENCES}

1. Yang F, Jacobs R, Willems G. Dental age estimation through volume matching of teeth imaged by cone-beam CT. Forensic Sci Int. 2006; 159 Suppl 1:S78-83. doi: 10.1016/j.forsciint.2006.02.031.

2. Fritsch F, Willershausen B, Gleissner C. Human dental age estimation by cone beam computed tomography-an in vitro study. J Forensic Odontostomatol. 2013;31:149-50.

3. Maber M, Liversidge H, Hector M. Accuracy of age estimation of radiographic methods using developing teeth. Forensic Sci Int. 2006;159:S68-S73.

4. Singh N, Grover N, Puri N, Singh S, Arora S. Age estimation from physiological changes of teeth: a reliable age marker? J Forensic Dent Sci. 2014;6(2):113.

5. Ghasemi M, Daneshparvar H, Nikmanesh V, Kharazifard M. Recommendation of a standard method for age estimation in iranian population based on two dental parameters. J Iranian Anat Sci. 2010;8:6775.

6. Babshet M, Acharya AB, Naikmasur VG. Age estimation from pulp/tooth area ratio (PTR) in an Indian sample: A preliminary comparison of three mandibular teeth used alone and in combination. J Forensic Leg Med. 2011 Nov;18(8):350-4.

7. Willems G. A review of the most commonly used dental age estimation techniques. J Forensic Odontostomatol. 2001 Jun;19(1):9-17.

8. Solheim T. Amount of secondary dentin as an indicator of age. Eur J Oral Sci 1992; 100(4):193-9.

9. Kvaal SI, Kolltveit KM, Thomsen IO, Solheim T. Age estimation of adults from dental radiographs. Forensic Sci Int. 1995 Jul 28;74(3):175-85.
10. Paewinsky E, Pfeiffer H, Brinkmann B. Quantification of secondary dentine formation from orthopantomograms--a contribution to forensic age estimation methods in adults. Int J Legal Med. 2005 Jan;119(1):27-30.

11. Landa MI, Garamendi PM, Botella MC, Alemán I. Application of the method of Kvaal et al. to digital orthopantomograms. Int J Legal Med. 2009 Mar;123(2):123-8. doi: 10.1007/s00414-008-0268-9.

12. Juneja M, Devi YB, Rakesh N, Juneja S. Age estimation using pulp/tooth area ratio in maxillary canines-A digital image analysis. J Forensic Dent Sci. 2014;6(3):160-5

13. Vultaggio $\mathrm{C}$, Cingolani M, Fornaciari G. Reliability in age determination by pulp/tooth ratio in upper canines in skeletal remains. J Forensic Sci. 2006 Jul;51(4):861-4.

14. Cameriere R, Ferrante L, Cingolani M. Variations in pulp/tooth area ratio as an indicator of age: a preliminary study. J Forensic Sci. 2004 Mar;49(2):317-9.

15. Sakhdari S, Mehralizadeh S, Zolfaghari M, Madadi M. Age estimation from pulp/tooth area ratio using digital panoramic radiography. J Islam Dent Assoc Iran. 2015;27(1):19-23

16. Różyło-Kalinowska I, Kalinowski P, Piskórz M, Namięta N. Age estimation by pulp/tooth area ratio in upper canines: Cameriere's method assessed and modified in a Polish population sample using digital panoramic radiography. Res Sq.. 2020:1-16. doi: 10.21203/rs.3.rs-19412/v1.

17. Kapoor N, Kothari P, Shukla R, Mishra S, Badiye A. Age estimation from tooth-pulp area ratio: A preliminary study. La Revue de Médecine Légale. 2020;11(1):11-4.

18. Cameriere R, Ferrante L, Cingolani M. Variations in pulp/tooth area ratio as an indicator of age: a preliminary study. J Forensic Sci. 2004 Mar;49(2):317-9.

19. Ubelaker DH, Parra RC. Application of three dental methods of adult age estimation from intact single rooted teeth to a Peruvian sample. J Forensic Sci. 2008 May;53(3):608-11.

20. Moshfeghi M, Ghojazadeh M, Sadrabad Z, Shadkar M, Shadkar Z. Age estimation in an Iranian population based on pulp/tooth area ratio (PTR). Res J Med Sci. 2014;8(3):116-20.

21. Haghnegahdar A, Vossoughi M, Teymoorienik Z, Khojastepour L. Evaluating the accuracy of Kvaal's method for age estimation in a selected Iranian population. J Dent Biomaterials. 2018;5(2):573-82.

22. Dehghani M, Shadkam E, Ahrari F, Dehghani M. Age estimation by canines' pulp/tooth ratio in an Iranian population using digital panoramic radiography. Forensic Sci Int. 2018;285:44-9.

23. Berkovitz BKB, Holland GR, Moxham BJ. Color atlas \& textbook of oral anatomy, histology, and embryology. 2nd ed. St. Louis: Mosby year book; 1992.

24. Philippas GG. Influence of occlusal wear and age on formation of dentin and size of pulp chamber. J Dent Res. 1961;40(6):1186-98.

25. Bang G. Age changes in teeth: developmental and regressive. In: Iscan MY. Age markers in the human skeleton. Charles C Thomas Pub Ltd; Springfield. 1989;p 213.

26. Solheim T, Vonen A. Dental age estimation, quality assurance and age estimation of asylum seekers in Norway. Forensic Sci Int. 2006 May 15;159 Suppl 1:S56-60.

27. Afify MM, Zayet MK, Mahmoud NF, Ragab AR. Age estimation from pulp/ tooth area ration in three mandibular teeth by panoramic radiographs: study of an Egyptian sample. J Forensic Res. 2014;5:1-5. 
28. Bosmans N, Ann P, Aly M, Willems G. The application of Kvaal's dental age calculation technique on panoramic dental radiographs. Forensic Sci Int. 2005 0ct 29;153(2-3):208-12.

29. Murray PE, Stanley HR, Matthews JB, Sloan AJ, Smith AJ. Age-related odontometric changes of human teeth. Oral Surg Oral Med Oral Pathol Oral Radiol Endod. 2002 Apr;93(4):474-82.

30. Stavrianos C, Mastagas D, Stavrianou I, Karaiskou 0. Dental age estimation of adults: a review of methods and principals. Res J Med Sci. 2008;2(5):258-68
31. Saxena S. Age estimation of indian adults from orthopantomographs. Braz Oral Res. 2011 May-Jun;25(3):225-9.

32. Jeevan MB, Kale AD, Angadi PV, Hallikerimath S. Age estimation by pulp/ tooth area ratio in canines: cameriere's method assessed in an Indian sample using radiovisiography. Forensic Sci Int. 2011 Jan 30;204(1-3):209. e1-5.

\section{Roghieh Bardal}

(Corresponding address)

Department of Oral and Maxillofacial Radiology, Dental Caries Prevention Research Center, Qazvin University of Medical Sciences, Bahonar Blvd., Qazvin, Iran. 